\title{
LARYNGOLOGY
}

\section{Tracheo-bronchial recurrent respiratory papillomatosis: role of powered instruments in overcoming surgical challenges}

\author{
Papillomatosi tracheale e bronchiale ricorrente: il ruolo della strumentazione avanzata \\ nel superamento delle sfide del trattamento chirurgico
}

\author{
Kapil Sikka1', Madan Gupta², Hitesh Verma', Rajeev Kumar' ${ }^{1}$, Alok Thakar ${ }^{1}$ \\ ${ }^{1}$ Department of Otorhinolaryngology, AIIMS, New Delhi, India; 2 Tata Memorial Hospital, Bombay, India
}

\begin{abstract}
SUMMARY
Objective. Respiratory papillomatosis involving the trachea is a challenging problem. In this paper, we present our experience in the management of 13 cases of tracheal papillomatosis and the difficulties encountered in the procedure. The surgical technique and results are discussed.

Methods. A modified transoral trans-stomal approach was employed for the removal of papillomas by using microdebrider. All patients were operated on under general anaesthesia with intermittent removal of intubation tube and apnoea. All patients required repeated surgeries. Tracheostomy removal was considered after adequate surgery and recurrence-free interval. The follow-up period was 12-24 months.

Results. The total number of surgeries per patient ranged from 3-35 (mean 10). Decannulation could be successfully achieved in 9 patients. There were no procedure-related complications.

Conclusions. Transoral trans-stomal microdebrider assisted excision of tracheal papilloma showed excellent results without procedure-related complications. It can be used as a routine procedure for tracheal papillomas. The prognosis of tracheal involvement is fair and most patients can be decannulated.
\end{abstract}

KEY WORDS: trachea, microdebrider, $\mathrm{CO} 2$ laser, trachesotomy, hemostasis

\section{RIASSUNTO}

Obiettivi. La papillomatosi respiratoria tracheale è un problema clinico impegnativo. In questo articolo, presentiamo la nostra esperienza nella gestione di 13 casi di papillomatosi tracheale e le difficoltà incontrate nel loro trattamento chirurgico. Vengono discussi la tecnica chirurgica ed i risultati.

Metodi. Un approccio transorale trans-stomale modificato con l'impiego di microdebrider. Tutti i pazienti sono stati operati in anestesia generale con rimozione intermittente del tubo di intubazione e transitorie brevi fasi di apnea respiratoria. Tutti i pazienti sono stati operati più di una volta. La rimozione della tracheotomia è stata presa in considerazione dopo interventi adeguati ed un lungo intervallo libero da recidive. Il periodo di follow-up è stato di 12-24 mesi.

Risultati. Il numero totale di interventi chirurgici per paziente variava da 3-35 (media 10). La rimozione della tracheotomia è stata ottenuta con successo in 9 pazienti. Non ci sono state complicazioni chirurgiche.

Conclusioni. L'escissione transorale trans-stomale assistita da microdebrider del papilloma tracheale ha mostrato risultati eccellenti senza complicazioni correlate alla procedura. Può essere utilizzato come procedura di routine per i papillomi tracheali. La prognosi del coinvolgimento tracheale è buona e la maggior parte dei pazienti può essere sottoposto a rimozione di cannula tracheale.

PAROLE CHIAVE: trachea, microdebrider, laser CO2, trachesotomia, emostasi
Received: May 1, 2020

Accepted: July 13, 2020

Correspondence

Hitesh Verma

Department of Otorhinolaryngology, AIIMS,

New Delhi, India

Tel. +91 01126594862 . Fax +9101126588663

E-mail: drhitesh10@gmail.com

Funding

None.

Conflict of interest

The Authors declare no conflict of interest.

How to cite this article: Sikka K, Gupta M, Verma $\mathrm{H}$, et al. Tracheo-bronchial recurrent respiratory papillomatosis: role of powered instruments in overcoming surgical challenges. Acta Otorhinolaryngol Ital 2021;41:146-150. https://doi. org/10.14639/0392-100X-N0822

() Società Italiana di Otorinolaringoiatria e Chirurgia Cervico-Facciale

\section{(c) (1) $(2)$}

This is an open access article distributed in accordance with the CC-BY-NC-ND (Creative Commons Attribution-NonCommercial-NoDerivatives 4.0 International) license. The article can be used by giving appropriate credit and mentioning the license, but only for non-commercial purposes and only in the original version. For further information: https:// creativecommons.org/licenses/by-nc-nd/4.0/deed.en 


\section{Introduction}

The management of respiratory papillomatosis (RP) involving the trachea can be extremely difficult and challenging. The incidence of tracheal involvement in recurrent respiratory papillomatosis is estimated at around 5\%, with $1 \%$ of cases having pulmonary involvement ${ }^{1}$. The challenges of endoscopic surgery of trachea are obvious, as the airway is shared with the anaesthetist. There is a risk of distal seeding of disease and difficulties are supplemented with a lack of standard instrumentation. In addition, patients with these lesions require multiple surgeries during the course of their illness. The literature on surgery of such tracheal lesions has been sparse and techniques are not standardised. Recent studies have demonstrated a technical advantage of a microdebrider in papillomatosis removal over lasers and conventional cold instruments ${ }^{2-7}$. In this paper, we present our experience on the use of a microdebrider in the management of tracheal papillomatosis and the difficulties encountered in the procedure. The surgical technique and results are discussed.

\section{Methods}

This retrospective study was performed in the Department of Otorhinolaryngology, Head \& Neck Surgery at All India Institute of Medical Sciences, New Delhi. A total of 56 RP patients were managed surgically during the study period (2013-2019). Thirteen cases with tracheal and pulmonary involvement were included in the current study. Surgical excision was performed after clinical diagnosis of RP and diagnosis was confirmed on histopathology. Six of the 13 patients received HPV detection and typing using a linear array HPV genotyping kit. Five of these had HPV 11 and one had HPV 6 infection. Adjuvant medical treatment was prescribed in two cases. Intralesional bevacizumab was administered on two occasions each in these 2 cases (Tab. I). One of these patients also received HPV vaccine Gardasil at 0,2 and 6 month intervals, and pegylated interferon for 4 weeks.

\section{Operative technique}

The modified transoral, trans-stomal technique for papillomatosis removal was performed. The blades were double curved with a small cutting point for adequate mucosal safety (Fig. 1). The patients were anaesthetised via a flexo-metallic tracheal tube. The patients were draped in such a way that the control of the cuff was under the surgical team. It allowed easy manipulation of the tube and cuff. Patients were placed in a microlaryngoscopy position and a laryngoscope was inserted and fixed with suspension. A rigid tracheoscope was introduced transorally, through the laryngoscope, for visualisation and suprastomal papillomas were debrided. Since control of both tracheoscope and debrider can be difficult for a single surgeon, an endoscope may be held in place by the assistant (Fig. 2). The stomal port was employed for introduction of the microdebrider for distal disease since the introduction of both tools through the stomal port was difficult. After adequate

Table I. Case summary of patients.

\begin{tabular}{|c|c|c|c|c|c|c|c|}
\hline $\begin{array}{l}\text { Age (at } \\
\text { presentation) }\end{array}$ & Sex & $\begin{array}{c}\text { Duration of } \\
\text { disease (years) }\end{array}$ & $1^{\text {st }}$ surgery & $\begin{array}{l}\text { Number of } \\
\text { surgeries }\end{array}$ & Decanulation & Final status & Adjuvant therapy \\
\hline 26 & M & 10 & 2006 & 13 & No & $\begin{array}{l}\text { Malignant } \\
\text { transformation }\end{array}$ & $\begin{array}{c}\text { Intralesional bevacizumab on } \\
\text { two occasions }\end{array}$ \\
\hline 38 & M & 34 & 1981 & 35 & Yes & No disease & None \\
\hline 39 & M & 3 & 2012 & 4 & Yes & No disease & None \\
\hline 34 & $\mathrm{~F}$ & 10 & 2004 & 3 & No & $\begin{array}{c}\text { Malignant } \\
\text { transformation }\end{array}$ & None \\
\hline 15 & M & 12 & 2001 & 12 & Yes & No disease & None \\
\hline 4 & M & 4 & 2009 & 14 & No & Persistent disease & $\begin{array}{l}\text { Intralesional bevacizumab, } \\
\text { gardasil and pegylated } \\
\text { interferon }\end{array}$ \\
\hline 9 & $\mathrm{~F}$ & 3 & 2010 & 4 & Yes & No disease & None \\
\hline 11 & M & 6 & 2007 & 6 & Yes & No disease & None \\
\hline 6 & M & 5 & 2009 & 5 & Yes & No disease & None \\
\hline 11 & M & 4 & 2008 & 3 & Yes & No disease & None \\
\hline 11 & $\mathrm{~F}$ & 3 & 2010 & 4 & Yes & No disease & None \\
\hline 8 & $\mathrm{~F}$ & 4 & 2009 & 5 & Yes & No disease & None \\
\hline 8 & M & 4 & 2011 & 20 & No & Persistent disease & None \\
\hline
\end{tabular}




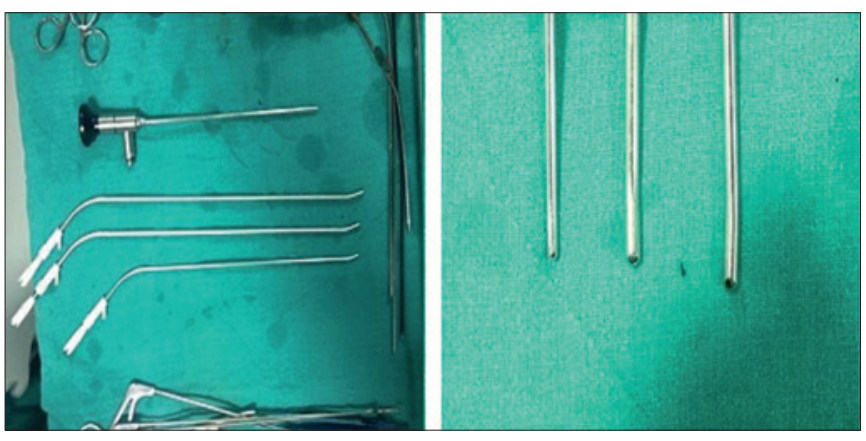

Figure 1. Microdebrider blades: Double curved shape and fine cutting edge facilitates precise and atraumatic debridement.

removal of suprastomal papillomas, and ensuring haemostasis, the tracheal flexo-metallic tube was removed and the patient maintained in apnoea. The apnoea time was used for debridement of distal tracheal papillomas with the microdebrider inserted through a stomal port (Fig. 2). Stomal collapse can be encountered making tube re-insertion difficult, after the apnoea time is over. This challenge is frequently observed in very young children and recent stomas. In such a scenario, two sutures at the stomal edges can be used to keep the stoma patent and as a traction tool for easy insertion of the tube. An assistant also holds additional flexible suction through a stomal port for clearing the airway of any blood and acts as an additional port of tissue suctioning to prevent distal seeding. We have found this important, as debrider suction can be insufficient for the bulk of tissue and blood. The debrider was thus controlled with both hands to clear lower airway papillomas. The rotating function of the laryngeal blade facilitated removal of the papilloma from all walls of the airway. The endotracheal flexometallic tube was reinserted after the apnoea time was over and the surgeon was signalled by the anaesthetist. The surgeon's control of the endotracheal cuff prevented undue handling of drapes. It also maintained the sterile surgical field and allowed control of cuff inflation site to achieve haemostasis, if carefully inflated at the site of debridement. A coblator was kept ready to coagulate any persistent bleeding, but it was not required in any case. The cycle of ventilation-debridement was repeated, until adequate clearance is achieved.

\section{Complications and pitfalls}

The tube insertion at end of apnoea time needs to be swift. An experienced and alert assistant can make it easier for the surgeon to focus on the main surgery. As already mentioned, the stomal sutures can be used as a traction device and make tube reinsertion easier.

Aspiration of blood, secretions and papillomas into the lower

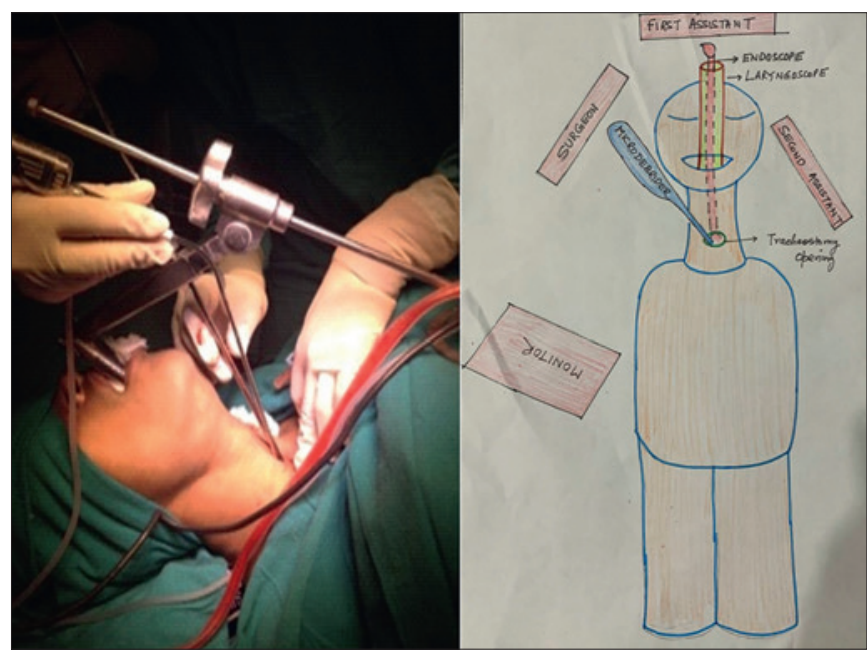

Figure 2. Demonstrating the trans-stomal port and surgical field (line diagram).

airways should be avoided. None of our patients had serious pulmonary complications related to surgery, but this is a theoretical possibility. Second suction by assistant and care of bleeding by the inflated cuff of flexible endotracheal tube took care of minor field bleeds. Coblation equipment should be kept handy in case of major bleeds. Poor surgical anatomy with high disease volume has higher chances of inadvertent injury of the complete luminal wall. The application of microdebrider blade below the first bronchus was very tricky. The surgery was staged to prevent undue complications. A final endoscopy check is paramount for adequate haemostasis and to prevent aspiration-related complications.

\section{Results}

Out of 13 patients, 9 were paediatric and 4 were adults with the same ratio of males and females. All patients presented with tracheostomy in situ and none had tracheostomy performed at the time of debridement. Tracheostomy removal was considered after adequate recurrence free interval. The follow-up period was 12-24 months. Relevant data are summarised in Table I.

Duration of disease ranged from 9-32 years (average 17 years) in adults and 2-12 years (average 7 years) in the paediatric group. The total number of surgeries ranged from 3-35 (mean 10). The disease was limited to the upper $1 / 3$ of the trachea in 5 patients, upper $2 / 3$ in 3 patients and the entire trachea in 5 patients. Two patients had pulmonary involvement (Fig. 3).

Decannulation could be successfully achieved in 9 patients. Two patients had pulmonary involvement that was identified by peripheral cavitary lesions on CT scan (Fig. 


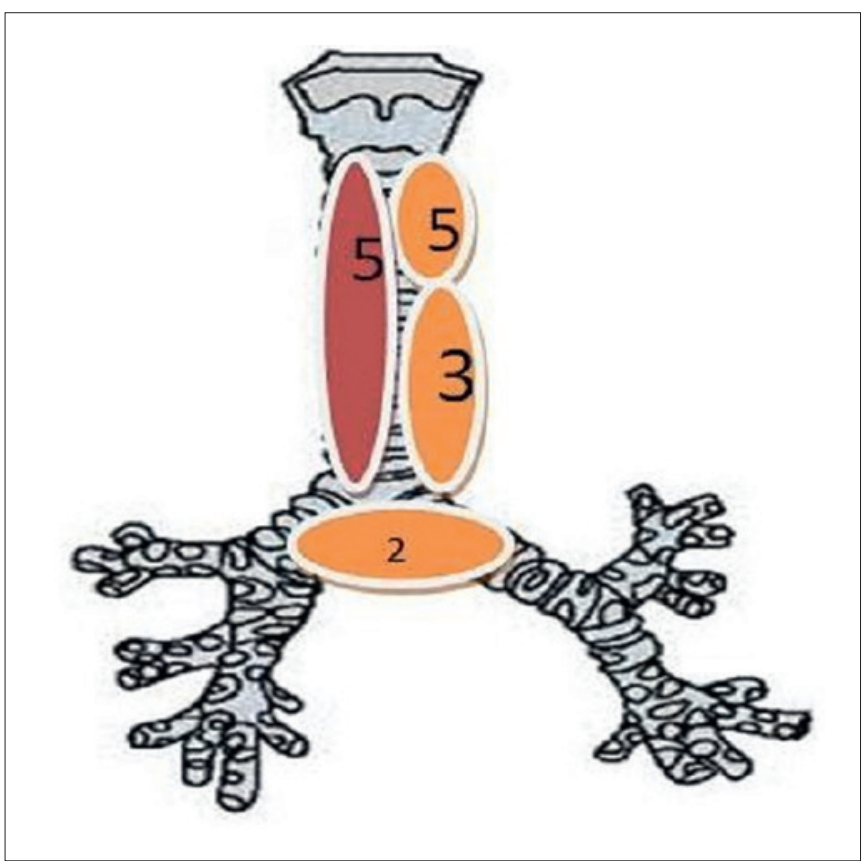

Figure 3. Emblazon trachea with subsite frequency showing upper one third in 5 , lower two third in 3 , whole trachea in 5 and pulmonary involvement in 2.

4). Neither of these patients with pulmonary involvement could be decannulated, with one developing malignant transformation. In the long term, two adult patients developed malignant transformation which recurred despite curative attempts with chemoradiotherapy and surgical salvage in one patient. There was no procedure related complication. The representative intraoperative and follow-up picture of one of the cases is presented in Figures $5 \mathrm{a}$ and $\mathrm{b}$.

\section{Discussion}

Surgical removal of tracheal papillomas is difficult and challenging. It requires an adequate simultaneous visualisation, instrumentation and ventilation.

Rees et al. ${ }^{3}$ described the use of the microdebrider for removal of tracheal papillomas in conjunction with visualisation by a rigid telescope. They noted that the small confines of the paediatric larynx do not allow simultaneous use of a ventilating bronchoscope and microdebrider in the trachea. Ulualp et al. ${ }^{4}$ described a technique for trans-stomal management of tracheal papillomas, where the bronchoscope and microdebrider are both introduced through the patient's stoma. However, the size of the ventilating bronchoscope is limited to 2.5 due to the constraints of stoma size. We have experienced similar constraints in inserting the tracheoscope and debrider blades through same stomal port, especially

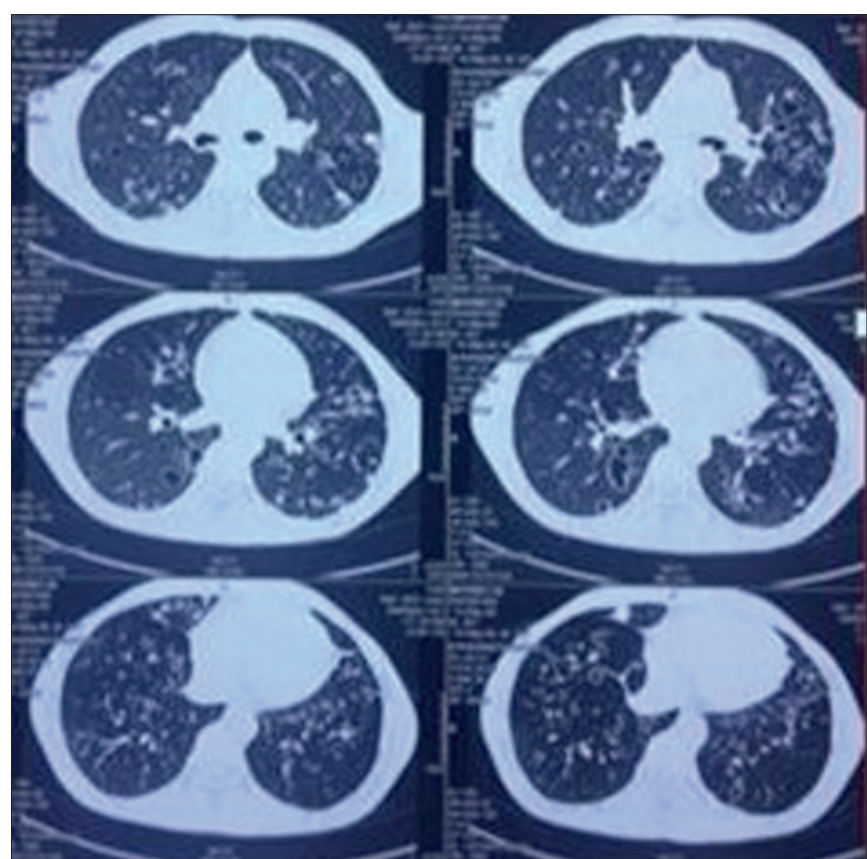

Figure 4. HRCT chest of a patient with pulmonary involvement showing multiple air filled cavities with thick wall in bilateral lung field.
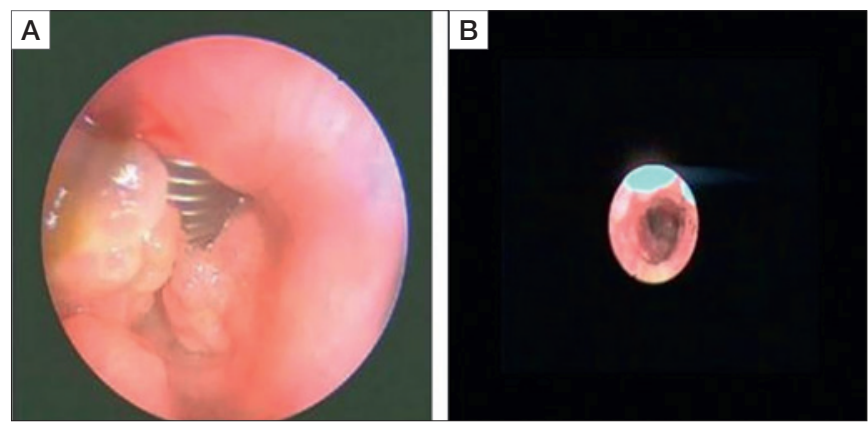

Figure 5. Intraoperative view of tracheal papillomas debrided with microdebrider inserted through stomal port. An additional suction can be seen to facilitate clearance of secretions. Right side picture is showing infrastomal trachea at 6 weeks follow-up of same patient.

in the younger age groups. Ventilation through a small 2.5 bronchoscope may be ineffective, especially in older children. Moreover, we experienced inadequate visualisation by insertion of the microdebrider blades through bronchoscope lumen. We prefer visualisation by a rigid telescope through an oral port, constantly maintained by the laryngoscope in suspension and hence, the debrider may be inserted through a stoma.

$\mathrm{CO} 2$ laser has been widely studied as a modality for the treatment of respiratory papillomatosis. Recent studies have reported that a microdebrider is a safe, effective, quick and cheaper option. In addition, the use of carbon dioxide 
laser in tracheal lesions is difficult with currently available technologies ${ }^{7,8}$. The technique, safety and efficacy of its usage in the lower airways have not been well documented. The majority of tracheal RP presented in the emergency department with some respiratory compromise, and we have found that the microdebrider is very convenient to handle with less installation time. Inbuilt irrigation and suctioning provide an additional advantage of content clearance of airways. A CO2 laser is also associated with a steeper learning curve than a microdebrider. Laryngeal debrider blades are relatively rigid, so the handing of papillomas was possible without extubation to a certain extent. In our experience, control of diode fiber laser was tricky, since the precision of its usage in high volume disease is lacking. It is very difficult to manipulate thin fibres over large areas in the distant airways.

Anaesthesia for endoscopic tracheal surgery is extremely challenging. The techniques of simultaneous ventilation by jet ventilation or by bronchoscope, though attractive, make working in the surgical field difficult. Additionally, there is a theoretical risk of distal seeding of papillomas. As per our experience, these patients tolerate intermittent apnoea well and apnoea provides ample time for the surgeon to achieve considerable debulking. There have been no cases of alarming airway bleed or postoperative aspiration related pulmonary complications. Considerable attention should be given to adequate clearance of secretions and blood along with debridement, at times, with the use of additional suction. A confirmatory endoscopy at end of the procedure should be performed to verify the adequacy of airway patency ${ }^{9,10}$. Malignant transformation of upper respiratory tract papillomatosis to squamous cell carcinoma is rare and occurs in less than $1 \%$ of patients ${ }^{11,12}$. In our study, two patients developed malignant transformation. Pulmonary involvement in such conditions presents as cavitary lesions in lung fields. The prognosis in such patients is always poor and they succumb to complications of pneumonia or severe airway compromise. Our experience with these cases is limited to 2 patients, both of whom are alive with repeated tracheal surgeries albeit with a tracheostomy.

\section{Conclusions}

Transoral trans-stomal microdebrider-assisted excision of tracheal papillomatosis shows excellent results without complications. It can be used as a routine procedure for tracheal papillomas. The prognosis of tracheal involvement is fair and most patients can be decannulated.

\section{References}

1 Soldatski IL, Onufrieva EK, Steklov AM, et al. Tracheal, bronchial, and pulmonary papillomatosis in children. Laryngoscope 2005;115:18481854. https://doi.org/10.1097/01.mlg.0000173155.57491.2a

2 Thorne MC, Zur KB. Transoral trans-stomal microdebrider excision of tracheal papillomatosis. Laryngoscope 2009;119:964-966. https:// doi.org/10.1002/lary.20163

3 Rees CJ, Tridico TI, Kirse DJ. Expanding applications for the microdebrider in pediatric endoscopic airway surgery. Otolaryngol Head Neck Surg 2005;133:509-513. https://doi.org/10.1016/j. otohns.2005.06.029

4 Ulualp SO, Ryan MW, Wright ST. Microdebrider removal of tracheal papilloma via tracheostomy in the child with an obliterated larynx. J Laryngol Otol 2007;121:1070-1072. https://doi.org/10.1017/ S002221510700775X

5 Kashima HK, Kessis T, Mounts P, et al. Polymerase chain reaction identification of human papillomavirus DNA in $\mathrm{CO} 2$ laser plume from recurrent respiratory papillomatosis. Otolaryngol Head Neck Surg 1991;104:191-195. https://doi.org/10.1177/019459989110400206

6 El-Bitar MA, Zalzal GH. Powered instruments in the treatment of recurrent respiratory papillomatosis: an alternative to the carbon dioxide laser. Arch Otolaryngol Head Neck Surg 2002;128:425-428. https://doi.org/10.1001/archotol.128.4.425

7 Pasquale K, Wiatrak B, Woolley A, et al. Microdebrider versus $\mathrm{CO} 2$ laser removal of recurrent respiratory papillomas: a prospective analysis. Laryngoscope 2003;113:139-143. https://doi. org/10.1097/00005537-200301000-00026

8 Yang QW, Xu W, Guo W. A retrospective analysis of $\mathrm{CO} 2$ laser and microdebrider for the treatment of severe juvenile on-set recurrent respiratory papillomatosis. Zhonghua Er Bi Yan Hou Tou Jing Wai Ke Za Zhi 2017;52:733-737. https://doi.org/10.3760/cma.j.is sn.1673-0860.2017.10.004

9 Nan BY, Chen BB, Zhang CQ, et al. Peri-operative management on juvenile recurrent respiratory papillomatosis. Zhonghua Er Bi Yan Hou Tou Jing Wai Ke Za Zhi 2012;47:454-457.

10 Lei W, Wen W, Su Z, et al. Comparison of intravenous general anaesthesia vs endotracheal intubation in the surgical management of juvenile onset recurrent respiratory papillomatosis. Acta Otolaryngol 2010;130:281-285. https://doi.org/10.3109/00016480903051643

11 Hartley C, Hamilton J, Birzgalis AR, et al. Recurrent respiratory papillomatosis - the Manchester experience, 1974-1992. J Laryngol Otol 1994;108:226-229.

12 Karatayli-Ozgursoy S, Bishop JA, Hillel A, et al. Risk factors for dysplasia in recurrent respiratory papillomatosis in an adult and pediatric population. Ann Otol Rhinol Laryngol 2016;125:235-241. https://doi. org/10.1177/0003489415608196 